\title{
Bernd Stegemann
}

Hochschule für Schauspielkunst „Ernst Busch” Berlin

e-mail: dramaturgie@hfs-berlin.de

\section{Realizm klasy mieszczańskiej}

W porzadku, istnieje walka klas. Ale to moja klasa, klasa bogatych, prowadzi tę walkę. I to my wygrywamy.

Warren Buffett

\section{Prawdziwe jest to, co przyjemne}

Jeżeli realizm rozumiemy jako metodę estetyczną, za pomocą której radzimy sobie z rzeczywistością, i jeśli warunkiem skuteczności takiego postępowania wyjaśniającego jest jego zakorzenienie w określonej postawie wobec świata, to zanim rozważymy kwestię stylu, musimy postawić pytanie o postawę realistyczną. Pytanie to zadać dziś trudno i bywa ono z miejsca wyśmiewane, lecz nie powinno nas to powstrzymać przed jego postawieniem. Ponieważ to, co prawdziwe, nie zawsze jest przyjemne.

Jeśli chce się wyprowadzić z równowagi dowolne grono artystów, wystarczy zadać im proste pytanie: Jaka jest wasza perspektywa klasowa? Pierwszą reakcją będzie zakłopotanie: Czy zadano to pytanie ironicznie, czy też na poważnie, czy jest ono błazenadą, czy też bezczelnością? Kiedy przestaną podejrzewać pytającego o ironię, zaczną wygłaszać slogany postmodernizmu: przecież klasy społeczne już nie istnieją; gdzie są ci wyzyskiwani robotnicy o brudnych twarzach, o których pisał Marks? A poza tym każdy z nas jest dzisiaj wysoko wyspecjalizowanym indywiduum, które daje się jedynie ulotnie przyporządkować do systemów funkcjonalnych: raz jest człowiekiem rodzinnym, raz niezdecydowanym wyborcą; zazwyczaj jest podatnikiem i zawsze konsumentem; coraz rzadziej, niestety, jest widzem teatralnym. 
Chciałoby się tutaj odpowiedzieć jednym zdaniem Theodora W. Adorna, którym już w 1942 roku podsumował on całą nędzę burżuazji:

Bezklasowe społeczeństwo kierowców samochodowych, widzów kinowych, towarzyszy narodowych drwi nie tylko z obcych, ale również z własnych zdominowanych członków, którzy do swojego zniewolenia nie odważą się przyznać ani przed sobą, ani przed innymi, ponieważ sama ta wiedza będzie karana bolesnym strachem przed utratą życia i majątku¹.

Współcześnie podobną diagnozę znaleźć można u Niklasa Luhmanna, twórcy teorii systemów, którego trudno podejrzewać o jakąkolwiek sympatię do socjalizmu. Jego zdaniem pojęcie klasy społecznej:

jest rzeczowo całkowicie słuszne, ponieważ istnieje fenomen, który ono opisuje, powiązany nierównomierny podział dóbr. Teoria klas nie musi się obawiać, że zostanie w tym aspekcie obalona, dopóki nie zniknie przedmiot jej zainteresowania, tzn. powiązany, nierównomierny podział dóbr. To pojęcie nie jest archaiczne².

Dlaczego więc współcześnie uważa się, że podział społeczeństwa na klasy, których przedstawiciele mają różne interesy i żyją w bardzo odmiennych rzeczywistościach, został przełamany? Czy rzeczywiście żyjemy w świecie, w którym nie ma już „powiązanego, nierównomiernego podziału dóbr"? Przypomnijmy sobie zatem podział na klasę proletariatu i burżuazji. Mieszczanin jako przedstawiciel swojej klasy charakteryzuje się tym, że wskutek alienacji zdeterminowany jest do ujednostkowienia. Żeby móc utrzymać swoją konkurencyjność, musi on uformować swoją biografię w historię sukcesu edukacyjnego. Sukces jego egzystencji opiera się więc na udanej indywidualizacji. Jego życie jest z konieczności wyjątkowe, w związku z czym związki pomiędzy faktami ujmuje on w subiektywnej perspektywie, w ramach której nie sposób myśleć o całości społeczeństwa. W przeciwieństwie do tego życie proletariusza jest do tego stopnia ukształtowane przez wyzysk i alienację, że droga do upodmiotowienia jest dla niego zamknięta. Jednocześnie totalność przymusu uniemożliwia mu popełnienie mieszczańskiego błędu polegającego na przyjmowaniu, że praca nad własną wyjątkowością jest pracą na rzecz realizacji interesu całej ludzkości. Jego emancypacja może być tylko rewolucyjna, ponieważ musi obalić całość mechanizmów ucisku. Dla proletariusza nie istnieje ratunek indywidualny.

1 T.W. Adorno, Reflexionen zur Klassentheorie, w: idem, Soziologische Schriften I, Frankfurt nad Menem 1979, s. 377.

2 N. Luhmann, Zum Begriff der Sozialen Klasse, w: Soziale Differenzierungen, Opladen 1985, s. 149 i n. 
Wydaje się, że ten schemat nie pasuje już do społeczeństw postfordowskich. Na skutek radykalnych zmian w stosunkach produkcji stracił on swoją moc krytyczną, a nawet zamienił się w swoje przeciwieństwo. Dzisiaj alienacja polega na całkowitym zawłaszczeniu wszystkich indywidualnych sił twórczych na rzecz wyzysku. Co zadziwiające, już w połowie XX wieku Adorno zauważył, że opisany przez marksistów podział klasowy został zniesiony w nowo powstałej masie globalnie wyzyskiwanych konsumentów. Opisywał on powiązanie pomiędzy przymusem dopasowania się do zmienionych stosunków produkcji a typowym dla burżuazji dążeniem do indywidualizacji. Polega ono na tym, że ekonomia efektywnie wykorzystuje, a nawet wzmaga siłę tych dążeń poprzez ofertę konsumpcji, która każdemu jako nabywcy obiecuje jego jednostkowe szczęście. Przymus jest uwewnętrzniany i staje się bodźcem do wypracowania subiektywnej wyjątkowości. Na gruncie radykalnej alienacji proletariuszy i partykularnej alienacji burżuazji powstaje kolektywna partykularyzacja nowej klasy „proletariackiego mieszczaństwa”’.

Nowsze teorie marksistowskie ${ }^{4}$ uwierzytelniają prognozy Adorna, w których opisuje on nową świadomość klasową jako reakcję na niespójność rzeczywistości i na reprodukcję takiego sfragmentaryzowanego życia.

Czasy, w których jeszcze można było budować barykady, są prawie tak samo martwe jak te, w których rzemiosło przynosiło zyski. Wszechmoc represji i jej niewidoczność są tym samym. [...] Różnica pomiędzy wyzyskiwaczami a wyzyskiwanymi nie jest na tyle wyraźna, by wyzyskiwani dostrzegali, że solidarność powinna być ich ultima ratio: konformizm wydaje się im bardziej racjonalny. Przynależność do wspólnej klasy od dawna nie przekłada się na wspólnotę interesu i działania ${ }^{5}$.

Tej przemianie człowieka w osamotnionego wojownika towarzyszy skupianie władzy gospodarczej w monopole. Tam, gdzie ludzie zostają ujednostkowieni, kapitał zyskuje pełnię władzy. „Całościowa organizacja społeczeństwa przez big business oraz jego wszechobecną technikę kompletnie opanowała świat i wyobraźnię do tego stopnia, że myśl, iż w ogóle mogłoby być inaczej, stała się prawie beznadziejnym wysiłkiem"6. Postmodernizm był nie tylko spełnieniem tej prognozy, ale również decydującym zwrotem prowadzącym do jej wypełnienia. Jego konsekwencji Adorno nie mógł przewidzieć, chociaż opisał je jako możliwe do pomyślenia w swojej teorii estetycznej. Myślenie postmodernistyczne nie tylko zmusiło jednostkę do wyzysku samej siebie

3 L. Kofler, Der proletarische Bürger, Wiedeń 1964.

$4 \quad$ Na myśli mam przede wszystkim kierunek postoperaizmu, który został opisany przez Michaela Hardta i Antonia Negriego w trzech tomach: Empire, Multitude oraz Commonwealth.

5 T.W. Adorno, Reflexionen..., s. 377 i n.

6 Ibidem, s. 376. 
poprzez odwrócenie odosobnienia w mieszczańską wolność. Ono również ograbiło ludzką świadomość ze środków, by potrafić o własnym losie inaczej niż tylko bezsilnie rozważać. Razem z dekonstrukcją środki myślenia i mowy zostały unieszkodliwione, tak że się nadają jedynie do identycznej refleksji nad chaotycznym życiem. Rzeczywistością jest teraz to, co nie pozwala na tworzenie powiązań, realistyczne jest jedynie to, co opisuje anarchistyczne współzawodnictwo właścicieli i ich interesów w rywalizacji rynkowej. Nie tylko produkty przemysłu kulturowego uformowały wyobraźnię nowej klasy proletariackiego mieszczaństwa do zestandaryzowanej indywidualności. Została również zniszczona samoświadomość, która za pomocą swojego myślenia i wyrażania się próbuje zrozumieć rzeczywistość i uczynić ją dla innych zrozumiałą. O ile u Adorna myśl krytyczna była hamowana poprzez strach przed upadkiem w społecznej hierarchii, dzisiaj uważa się za dowiedzione, że takie myślenie jest pozbawione sensu. Prędzej możemy sobie wyobrazić koniec świata niż koniec kapitalizmu.

Historia klas składa się z historii ekonomicznych monopoli, ludzkiej alienacji oraz w jej postmodernistycznej fazie - również z historii uległości myśli wobec złożoności systemów. Dzisiaj myśl zsynchronizowała się z pieniądzem pomnażającym pieniądz i maszynami wytwarzającymi maszyny. W ten sposób poświęciła ona swoją wolność i wewnętrzną nieskończoność na pojęcie złej nieskończoności autoreferencji systemowych. Zatomizowanie znaków i zależności usprawnia myśl w celu spełnienia instrumentalnych wymagań, które świat pracy i strumienie informacji co sekundę na nie nakładają. Nadmiernie pobudzona myśl próbuje nadążać za rytmem pieniądza i komunikacji, myląc przy tym nagonkę performance'u z własnym życiem.

Klasa proletariackiego mieszczaństwa połączyła mieszczańską sprzeczność polegającą na chęci bycia panem i niewolnikiem w jednej osobie z proletariackim wyobcowaniem, czyli byciem jedynie środkiem, a nie celem produkcji. Z partykularnej świadomości rozwiniętej mieszczańskiej indywidualności powstała wysoce wyspecjalizowana siła produkcyjna, która nareszcie może zostać wyzyskana jako cały podmiot. Dlaczego nowa klasa nie może samej siebie pojąć jako klasy? Brakuje jej świadomości, która pozwoliłaby myśleć o własnym życiu inaczej, niż na to pozwalają materialne warunki życia. Brakuje odwagi i zaufania we własną władzę sądzenia, by pojmować otoczenie inaczej, niż ono tego od nas oczekuje. I brakuje również pracy niezbędnej do tego, by nauczyć się pojmować własne dzieje. Język, który kiedyś istniał, by ową dialektykę móc sformułować, prawie zaginął.

W 1964 roku Leo Kofler przedstawił w pracy Der proletarische Bürger konkretny opis tego upadku:

Proces społeczny uniezależnia się w stosunku do człowieka, przyjmując postać rzeczowej, naturalnej władzy, która mu zagraża jako jego „zewnętrzny los”. Zdolność do dostrzegania tej władzy spada do minimum. Wiąże się to z niezdolnością pojedynczego indywiduum do pojęcia własnej sytuacji. Kolejną konsekwencją jest bycie 
opanowanym poprzez uprzedmiotowioną zasadę rzeczywistości. Polega ona na tym, że zainteresowane tym siły wmuszają człowiekowi coraz to nowe cele, które skłaniają go do dobrowolnego podjęcia wyobcowanej i uprzedmiotowionej pracy bez nadziei na rzeczywiste spełnienie obietnicy szczęścia, które miałoby nastąpić po ich osiągnięciu. Konsekwencją jest również sprzeczność pomiędzy dążeniem do postępu a bezwładnym pozostawaniem uwięzionym w tej samej, społecznie-uprzedmiotowionej i ludzko-spauperyzowanej pozycji. Wiąże się z tym również sprzeczność pomiędzy byciem podmiotem, które należy uznać za czynność wręcz histeryczną, oraz byciem zaledwie obiektem, faktycznym nicnierobieniem. Jedną z najważniejszych sił napędzających negatywną zasadę rzeczywistości jest podążanie za własnością, która obiecuje wolność, lecz przywiązuje pojedynczą osobę na całe życie do wyobcowanej pracy w służbie reprodukcji tej własności. Stąd wyłania się panowanie „umierającego” czasu, to znaczy czasu nietwórczego i sprowadzającego życie do niekończącej się kariery. Organicznie łączy się z nim wyobcowanie - uprzedmiotowiony czas wolny i „,kultura", która nie przynosi jednostce wyzwolenia, lecz zamiast tego pomaga całkowicie podporządkować się ogólnemu procesowi uprzedmiotowienia. Tak ukształtowana sytuacja człowieka znajduje na koniec swoje odzwierciedlenie w uprzedmiotowionej ideologii, dzięki której te wszystkie przykładowo wspomniane momenty same się objaśniają i ontologizują jako absolutnie „naturalne”7.

Jeżeli kogoś nadal razi pojęcie „,klasy”, może zastąpić je terminem technicznym „Związek nierównomiernej dystrybucji” lub poprzez „myślenie krytyczne”, które nie poddaje się „naturze”, lecz potrafi samo siebie pojąć w swojej zależności od warunków życia. Istotne w idei świadomości klasowej jest, by nie uznawać własnego życia za przypadkowego wyjątku, lecz by stosunek podmiotu i świata decydował o możliwościach pojmowania siebie i swoich dziejów.

Powyższa świadomość pomaga wyobrazić sobie współczesność inaczej, niż wymaga tego od nas odruchowa elastyczność. Umożliwia fantazje, w których własne dzieje przedstawiają się inaczej niż na obrazach, które wytwarza świat produktów i które służą wyłącznie konsumpcji. Pomaga w historycznym myśleniu, którego postęp nie jest mierzony w cyklach produkcyjnych Apple i Co. tylko w aktualnym rozwoju kulturowym.

Lecz co mogłoby być dzisiaj podstawą takiego samo-oświecenia? Pierwszy krok polega jak zawsze na rozpoznaniu, że istnieje potrzeba oświecenia. Nowa klasa proletariackiego mieszczaństwa musi się sama rozpoznać i zaprzestać mylenia własnej postaci właściciela z klasą kapitalistów. Pomocne może być tutaj przypomnienie, że w marksistowskim podziale rozróżniane są tylko dwie klasy: ci, którzy żyją ze swojego kapitału, oraz ci, którzy muszą swoją siłę roboczą sprzedawać. W tym momencie każdy mógłby sobie zadać pytanie, do której z obu tych klas przynależy.

$7 \quad$ L. Kofler, Der proletarische..., s. 62. 
Klasa średnia rozporządza w większości przypadków kapitałem, który zaoszczędziła, by zabezpieczyć się na starość, by kupić nieruchomość lub sfinansować wykształcenie dzieci. Jak u każdego prawdziwego kapitalisty ten kapitał powinien przynosić możliwie wysokie dywidendy. Odczuwana przynależność kapitału klasy średniej do klasy kapitalistów przeocza decydującą różnicę: kapitał, który służy oszczędzaniu, nie jest kapitałem w postaci środków produkcji generujących dywidendę, z której właściciel mógłby żyć. On jest przejściową formą przechowywania, która próbuje się posługiwać tymi samymi narzędziami kapitałowymi jak prawdziwy kapitał, lecz w swoim indywidualnym kroju nie ma tego samego działania. Jej właściciel nie może z dywidendy żyć i w najrzadszych przypadkach ma wpływ na to, z czego ona będzie gospodarowana oraz jaką będzie miała wysokość. Kapitalista klasy średniej jest z tego powodu bliżej spokrewniony z pięćdziesięcioma procentami społeczeństwa, które nie posiadają żadnej własności sięgającej poza codzienną konsumpcję, niż z prawdziwymi kapitalistami.

Gdy się przezwycięży tę małą, ale istotną niedokładność w określeniu klas, pozostanie jeszcze odczuwana przez klasę średnią przynależność do wygranych kapitalizmu. Dlaczego ci, którzy najwyraźniej nie dysponują środkami ekonomicznymi wystarczającymi do tego, by żyć jako kapitaliści, chcą uparcie myśleć i podejmować decyzje jak kapitaliści? Odpowiedź jest zdumiewająca, ponieważ leży ukryta w zwrotności ja-performance'u. Większość z tych, którzy w ogóle sobie to pytanie stawiają, dysponuje do tego niezbędnym czasem, dobrym wykształceniem i ma zainteresowania. Potrzeba, by uformować siebie jako klasę walczącą o zmianę świata, jest równa zeru. Jednocześnie ich preferencje smakowe orientują się na zasadzie skapywania wszystkich modnych nurtów. To, co pochodzi z wyższych warstw, jest godne pożądania. Zabezpieczona pozycja proletariackiego mieszczanina jest jednak anachronizmem. Pochodzi ona z czasów, gdy socjalizm ograniczał zakres panowania kapitalistycznej gospodarki rynkowej, co pozwalało klasie średniej na akumulację kapitału

Od czasu lat osiemdziesiątych kapitalizm przeszedł w fazę postmodernistyczną. Odtąd za pomocą nowej broni walczy on o inne cele niż dawny „kapitalizm oswojony”. Pod sztandarem neoliberalizmu zwyciężył nowy porządek gospodarczy, który w międzyczasie zaczął obowiązywać globalnie jako aktualna rzeczywistość ekonomiczna oraz jako jedyny sposób jej rozumienia. Zasada neoliberalizmu zawdzięcza swoją skuteczność temu, że przy jej wprowadzaniu posłużono się podstępem polegającym na uczynieniu jej niewidoczną. Zasada brzmi: rynek reguluje wszystko. I jedynie wolny rynek jest w stanie wszystkim regulować.

8 Prawie wszystkie środki, które zostały do tej pory zakumulowane, zostaną w ciągu najbliższych dziesięciu do dwudziestu lat odziedziczone. W efekcie po raz kolejny zwiększy się dystans pomiędzy kapitalistami a resztą społeczeństwa. Świadczy to o tym, że akumulacja kapitału klasy średniej osiągnęła swój najwyższy pułap. Poprzez pracę nie można już nic zyskać, a im bardziej rynki ulegają neoliberalnej transformacji, tym bardziej zwiększa się dystans pomiędzy gigantycznymi zyskami i niewielkimi dochodami. Przyszli wygrani, oprócz nielicznych wyjątków, nie będą więc pochodzić z klasy średniej. 
Ingerowanie w rynek, obojętnie w jaki sposób, stanowi przeszkodę, która wpływa na jego poprawne działanie. Podobnie jak w przypadku każdego prawdziwie skutecznego sposobu wyjaśnienia świata klęski stają się jedynie dowodem na poprawność własnych twierdzeń:

- Neoliberalna rewolucja nie doprowadziła do obiecanego dobrobytu dla wszystkich.

- Tak, to prawda, ale jedynie dlatego, że niektóre sektory rynku nadal są kontrolowane przez państwo.

- Rozregulowane rynki finansowe załamują się i muszą być ratowane przez społeczeństwo za pomocą astronomicznych kwot.

- Tak, to prawda, ale powód jest ciągle ten sam: neoliberalna rewolucja nie jest w pełni zakończona, nauka nie w pełni wcielona w życie.

Obietnica raju, do którego droga jest niestety wybrukowana trupami, a który urzeczywistni się dopiero na samym końcu, znana dotąd jedynie z dziejów rewolucji socjalistycznej, została całkowicie i bez ogródek przejęta przez rewolucję neoliberalną.

W tym miejscu neoliberalizm uniknął największego błędu socjalizmu: udało mu się ustrzec sprawiania wrażenia bycia ideologią. W rezultacie dyskusja o ideologii neoliberalnej stała się niemalże niemożliwa. W efekcie klasa średnia nadal wierzy, że należy w świecie kapitalistycznym do wygranych i może się tym przywilejem rozkoszować bez nadmiernie złego sumienia.

Umyka jej przy tym kompletna przebudowa struktury społecznej państw kapitalistycznych, zarówno tych rządzonych demokratycznie, jak i poprzez państwowe monopole. Pionierami, obok Stanów Zjednoczonych i Wielkiej Brytanii, były przede wszystkim Chiny oraz dawne Republiki Radzieckie, które przeszły jednym skokiem od socjalizmu do neoliberalnej oligarchii. Na ich przykładzie widzimy, jak dobrze pasują do siebie niepełna demokracja i neoliberalny porządek i jak wiele potrafią wspólnie osiągnąć. Bogactwo całego kraju jest skupione w rękach jednego procenta klasy panującej. Pozostałe dziewięćdziesiąt dziewięć procent ludzi dzieli się na trzy warstwy klasy niższej: gorzka bieda, przeciętna bieda i niemal znośne życie. Klasa średnia zniknęła albo nigdy nie istniała. Nie wolno dopuścić do jej odrodzenia, ponieważ jest ona podstawą mieszczańskiej kultury, w której prawa człowieka, równouprawnienie i wolna publiczna sfera należą do wartości fundamentalnych. Realizacja tego rodzaju roszczeń do lepszego życia nie leżała nigdy w interesie kapitału. Nie da się za ich pomocą zarobić żadnych pieniędzy, a podczas podejmowania decyzji politycznych prowadzą one jedynie do szkodliwych zakłóceń i aroganckich żądań reglamentacji wyzysku. Neoliberalizm ma sprawdzoną odpowiedź: to rynek podejmuje decyzje, a nie ludzie. A decyzje podejmowane są zgodnie $\mathrm{z}$ rachunkiem zysków i strat.

Niemiecka klasa średnia znajduje się oczywiście w kompletnie innej kondycji gospodarczej niż byli proletariusze krajów socjalistycznych, którzy stali się ubogimi, podwójnie pozbawionymi praw. Wciąż dobrze zabezpieczone życie w Europie Zachodniej dostarcza finansowego bufora przede wszystkim generacji spadkobierców, 
dzięki któremu osobiste aspiracje dają się bez ryzyka urzeczywistniać. Do tych aspiracji wciąż należy sztuka pisania, malowania i gry aktorskiej. I w ten sposób co roku napierają tysiące do krajowych akademii sztuk pięknych i tworzą prawie jednolity obraz: synowie i córki z dobrych domów pielęgnujący swoje gusta i idiosynkrazje. Albo jak to ujmowano w innych czasach: w swoich wychuchanych duszach marzący o dzikim życiu. Dzisiaj wszyscy wyznają credo postmodernizmu: Nie istnieje żadna prawda. Dlatego sztuka, która próbuje objaśniać nieprzyjazny świat, jest tylko pouczaniem. A pouczanie jest złe!

Połączenie indywidualizmu z bezpieczeństwem ekonomicznym prowadzi do rozkwitu postmodernistycznego poczucia smaku: brak zobowiązań wśród awangard oraz ich zmysłowe puenty będą wykorzystane do wypracowywania zwycięstw wrażliwości nad realizmem. Utrzymywanie, że nie istnieje żadna prawda, pasuje do własnego poczucia pełni życia, w którym wszystko wydaje się przejściowe i nie do końca ustalone. Wieczne „być może” staje się odczuwaną prawdą w zabezpieczonym życiu, posypuje przyprawą nadającą codziennej rutynie smak przygody.

Konsekwencje przyjęcia takiego światopoglądu są trudne przede wszystkim dla tych, którzy nie mają bogatych rodziców, ale podejmują ryzykowne przedsięwzięcie podążania artystyczną ścieżką zawodową. Pozbawia się ich możliwości ujęcia własnej niedoli jako problemu systemowego, a do tego wyśmiewa się wszelkie próby znalezienia takiego opisu. Zmuszeni są do przyjęcia swojej egzystencji jako pojedynczego losu, który musi swoją wartość w rywalizacji rynkowej wywalczyć. Lecz ten rynek będzie zdominowany poprzez idiosynkratyczną sztukę tworzoną przez spadkobierców, którzy swoją przewagę, brak potrzeby zarabiania pieniędzy, wykorzystują dla zysku w postaci doskonalenia swojego gustu.

Współczesna generacja młodych dorosłych otrzymała swoją nazwę od kampanii reklamowej - tak jakby sam duch naszych czasów przemienił ją w obraz. Hasło Don't be a Maybe należące do koncernu tytoniowego było tak popularne wśród generacji dwudziesto- i trzydziestolatków, że aż zostało zabronione. Narodziła się generacja Maybe 9 . Jej znakiem rozpoznawczym jest bezwzględne żądanie wolności idące w parze z paradoksalną świadomością, że posiada się wszelkie możliwości udanego życia, lecz nie jest się w stanie wystarczająco ich wykorzystać. Wiara w życie w najlepszym z możliwych światów, którego jednostka nie może w pełni skonsumować, prowadzi do powstania zagmatwanej mieszanki wolności, strachu i niezdecydowania. Oni są niewolnikami w przypadkowości Maybe. Czują ciągły napór wiecznie przegapianych ofert. A ponieważ winę za osamotnienie odczuwane wobec natłoku możliwości przypisuje się podmiotowi, udręki pokolenia Maybe przypominają męki tego, kto pośród nadmiaru nie zaznaje zaspokojenia. Wszystko wymyka im się z rąk w momencie, kiedy to chwycą, ponieważ to, co zostaje wybrane, nie może sprostać porównaniu do tysięcy

9 O. Jeges, Generation Maybe. Die Signatur einer Epoche, Berlin 2014; B. Heinzlmeier, Performer, Styler, Egoist, Berlin 2013. 
odrzuconych możliwości. Pytanie o udane życie, które dla mieszczańskiego podmiotu wiązało się zawsze z pytaniem o sprawiedliwość, znalazło swoją ostatecznie egoistyczną odpowiedź: prawdziwe jest to, co przyjemne.

Można tu zgłosić zarzut, że taki luksusowy problem dotyczy jedynie niewielkiej części ludzkości, bowiem nawet w bogatych krajach Europy Zachodniej zaledwie mała warstwa może sobie pozwolić na tę męczącą i pozbawioną sensu formę życia. Być może tak jest, lecz w tej części społeczeństwa dotyczy to również ludzi, którzy na podstawie swojej zabezpieczonej egzystencji czują się szczególnie powołani, by poświęcać swój czas na czynności twórcze i wypowiedzi artystyczne. Jedynie poprzez skierowanie uwagi na położenie klasowe tych artystów zarówno przez nich samych, jak i przez resztę społeczeństwa możliwe będzie głębsze zrozumienie tak wytworzonej sztuki. Dopiero gdy każdy artysta uświadomi sobie swoją przynależność klasową, będzie mogła powstać realistyczna świadomość naszych czasów. Ponieważ jednak taka przynależność jest właśnie ostatnią rzeczą, którą skłonni byliby w sobie zaakceptować, reprodukuje się nadal domknięcie postmodernistycznego podmiotu, który jest nieskrępowany w swoich poczynaniach życiowych, w kręgu autoreferencji. Ich wizja siebie, ich gusta oraz ich fantazje podążają za tym samym paradoksalnym credo, zgodnie z którym nie ma prawdy poza subiektywnością. Tym samym spełniają oni ekonomiczny wymóg permanentnego rewolucjonizowania sił wytwórczych.

\section{Autentyczny mieszczanin}

Pytanie o wyróżniki, w odwołaniu do których klasa może pojąć sama siebie, znalazło w postmodernizmie typową dla tego czasu odpowiedź: klasa średnia jest klasą tych, którzy klasą nie są. Jeśli się jednak na tym nie poprzestanie i zada kolejne pytanie, ten ładny paradoks może pęknąć. Zadajmy więc drugie, decydujące pytanie: Co jest piętą achillesową tej klasy? W XIX wieku czułym punktem klasy mieszczańskiej była jej podwójna moralność, za którą miała się skrywać sprzeczność bycia w jednej osobie zarówno wyzyskiwaczem, jak i wyzyskiwanym. Później podwójna moralność i towarzysząca jej fałszywa świadomość musiały zostać ukryte: kto uważa się za wyzyskiwacza, musi czuć się winnym według własnych kryteriów, kto natomiast uważa się za wyzyskiwanego, myśli nad formą praktyki, która zrewolucjonizuje istniejące stosunki. Klasa mieszczańska rozwiązała ten dylemat, wymyślając kolejne życiowe kłamstwa mające tę sprzeczność ukryć. Psychiczna praca wyparcia prowadziła do neuroz, podczas gdy ucisk społeczny miał swój wyraz w pełnym przemocy państwie. Znaczącą rolę w kształtowaniu wewnętrznej przestrzeni kapitału zajęła sztuka mieszczańska. Mocny silnik, który napędzał jej fantazję, czerpał energię z dążenia do ukrycia sprzeczności przed samym sobą i przed światem. Mieszczanin chciał sprawiać wrażenie niewinnego i pracowitego, nawet jeśli był winnym i wyzyskanym. Pragnął rozkoszy, ale z wartością dodatkową, i domagał się rozrywki, ale na poziomie. 
Od czasu, kiedy mieszczaństwo stało się klasą dominującą, aż do jego postmodernistycznego rozpadu towarzyszy mu pewien stały element, który obrazuje ową pracę nad dobrym uduchowieniem: tęsknota za autentycznością. Sprawianie autentycznego wrażenia jest dla mieszczaństwa niczym znak jakościowy, który potwierdza, że jego koncepcja wyparcia skutecznie działa. Autentyczne oddziaływanie narodziło się wraz z nowoczesnością i stanowi konstrukcję dialektyczną. Chce nadać podmiotowi wiarygodność i jest przy tym w zdumiewający sposób amoralna. Morderca z namiętności jest bardziej fascynujący jako zjawisko autentyczne niż utrapiona neurozami żona. Żona cierpiąca z powodu miłości do innego mężczyzny jest autentyczna, natomiast jej mąż, który przymyka oczy na jej dramat, by nie wywołać skandalu, nie jest autentyczny.

Oddziaływanie autentyczności nie jest związane z faktyczną, moralną treścią działania, lecz z intensywnością motywacji. Gdy podmiot nie jest już w pełni odpowiedzialny za swoje działanie, kiedy jego postępowaniem kieruje siła, której nie da się kontrolować, wówczas mieszczański podmiot czuje się wyzwolony ze swojej wyobcowanej sprzeczności. Autentyczność nie jest już tym, czym była niegdyś - suwerennym działaniem ,z własnej woli”, zamiast tego polega na uległości wobec siły wyższej. Bycie autentycznym nie jest świadectwem cnoty ani braku cnoty. Autentyczność stała się kategorią amoralną, dzięki której podmiotowość może się ukazywać jako głębsza, niż pozwalają na to zachowania „cywilizowane” będące przejawem alienacji.

Ponieważ mieszczański podmiot wie, że jego egzystencja rozdarta jest sprzecznościami, jego tęsknota za momentem prawdy jest ogromna. Moment autentycznego działania polega na podwójnym kłamstwie, które w realiach mieszczańskiej alienacji ukazuje się jako wyzwolenie. Wrażenie autentyczności sprawia ten, kto traci nad sobą kontrolę i nie przestrzega konwenansów; jego otoczenie doznaje wówczas autentyczności, co na moment uwalnia wszystkich od wątpliwości dotyczących braku prawdy w wyobcowanym życiu. Domniemywa się, że można wówczas dostrzec prawdziwą istotę drugiej osoby. Niewierna cudzołożnica i amoralny osiłek napędzani namiętnością są zatem autentyczniejsi od mieszczanina, który zbyt wyraźnie sili się, żeby ukryć wewnętrzną sprzeczność. W pojęciu autentyczności zawiera się przeinaczenie moralności i wiarygodności, które wywodzi się z fundamentalnego wyobcowania społeczeństwa mieszczańskiego i które dla społeczeństwa przedmieszczańskiego byłoby całkowicie niezrozumiałe i niemoralne. Pozór oryginalności jest ceniony wyżej niż skutki postępowania. Pomylenie autentyczności działań z ich moralną słusznością jest błędem w sposób konieczny wynikającym z wyobcowania.

Mieszczanin znajduje się w nierozwiązywalnej sprzeczności i dokładnie tę sprzeczność w jej wypartej formie czyni istotą swojego indywidualnego charakteru oraz tym samym - charakteru swojej klasy. Dlatego wszystkie indywidualne starania, aby sprzeczność tę rozwiązać, skazane są na niepowodzenie. Mieszczanin pęta się w sidła, które tym mocniej się wokół niego zacieśniają, im bardziej stara się z nich uwolnić. Walka ta stanowi właściwe źródło neurotycznej energii typowej dla mieszczańskiej egzystencji. 
Żywi się ona małymi, codziennymi zwycięstwami nad wewnętrznym oporem oraz wielką nadzieją na zbawienie poprzez stanie się autentycznym. Miłość romantyczna, tak samo jak piękny pozór sztuki, zostaje uwznioślona jako fantazmat konieczny. Uczucie nie jest już stanem wyjątkowym, lecz raczej dowodem na to, że sprzeczności da się rozwiązać w pewnym magicznym momencie. Jednak w społeczeństwie mieszczańskim wszystkie fantazje rozpłynięcia się w miłości będą kłamstwem, ponieważ nie można przeżywać ich w sposób naiwny jako elementu cudowności; muszą stanowić wykalkulowane dowody na prawdę egzystencji. Uczucia zapewniają tylko pozór udanego życia.

Dzięki dążeniu do autentyczności doskonale udaje się zapomnieć o dwoistym, sprzecznym charakterze mieszczaństwa bez potrzeby zmieniania czegokolwiek w warunkach jego istnienia. Ponieważ autentyczność nie służy do tego, by sprzeczności znieść lub uznać je za prawdę egzystencji, lecz po to, by w codziennych działaniach życiowych robić wrażenie pozbawionego sprzeczności i tym samym prawdziwego. Sposób ubierania się, komunikacji oraz ekspresji uczuć staje się miarą ludzkiej wiarygodności. Działanie autentyczne jest najefektywniejszą techniką utrzymywania uprzywilejowanej pozycji w ramach istniejącej hierarchii. Tęsknota klasy mieszczańskiej za autentycznością jest tym samym oparta na podwójnym życzeniu: pragnie się wyzwolenia z wyobcowania, które jest fundamentem własnej klasy, bez jakiejkolwiek utraty przywilejów własnej klasy. Jednocześnie podmiot dąży do tego, by ukryć własne sprzeczności, ponieważ bez tego nie sposób odnieść żadnego sukcesu. W tej tęsknocie za autentycznością manifestuje się sprzeczność mieszczańskiej formy życia: pragnie się wyzwolenia bez rewolucji, a środki służące do tego wyzwolenia powinny jednocześnie służyć podniesieniu konkurencyjności. Nie chce się wyobcowanego życia, a od życia pozornie niewyobcowanego oczekuje się, że zapewni ono większe zyski zarówno w sferze zawodowej, jak i w prywatnej.

Sprzeczność ta przejawiała się coraz silniej w historycznym rozwoju klasy mieszczańskiej. Nerwica natręctw, ważna choroba XIX wieku, była psychicznym odzwierciedleniem uwewnętrznionego przymusu bycia panem i niewolnikiem w jednej osobie. Stosunki pracy właściwe dla fordowskiej organizacji przemysłu wymagały jeszcze mocnego wyparcia własnych doświadczeń wyobcowania. Dzisiaj postfordowski przemysł kapitalizmu emocjonalnego dla podniesienia wydajności korzysta z powszechnej skłonności do samooszukania: nikt nie chce dziś pracować w sposób wyalienowany, lecz kreatywnie. Wszyscy wykonują taką pracę, jaką chcą, ale o tym, czego chcą, decyduje rynek. W konsekwencji chorobą naszych czasów jest depresja. Odpowiedzią rynku na wyczerpanie i zwątpienie nie jest zmiana warunków życiowych i stosunków pracy, lecz wytworzenie produktów rozrywkowych, które powinny przywrócić wesołość umęczonym duszom.

W drugiej połowie XX wieku powstaje globalny sektor przemysłu kulturowego, który oferuje coraz to nowe środki dopingujące dla wypłowiałych dusz. Punktem najbardziej czułym na te zachęty jest tęsknota klasy mieszczańskiej za autentycznością. W niekończących się cyklach mody popkultura i komercyjny realizm hollywoodzkiego kina oferują ekrany służące do projekcji autentycznych uczuć. Zmieniające się w nich szaty i kategorie 
estetyczne nie są w stanie ukryć, że dąży się tu do zaspokojenia ciągle tej samej, związanej $\mathrm{z}$ alienacją tęsknoty za pełnią życia. Autentyczni są zbuntowani mężczyźni rock and rolla i równie autentyczne są sztuczne postacie popu składające się z cytatów zmieniających się co miesiąc jak trendy w H\&M. Ponieważ w naszej wszechogarniającej współczesności ostatecznie wszystko jest cytatem oraz wszystko jest ironią, wyrazem autentyczności staje się mieszanie cytatów w odpowiednich proporcjach. Taki korowód mód będzie trwał dopóty, dopóki autentyczność pełni kluczową rolę w ukrywaniu sprzeczności mieszczańskiej. Zdecentralizowany postmodernistyczny podmiot dawno temu pogodził się ze swoim wyobcowaniem dzięki temu, że mógł je przemianować na swoją osobistą wolność: $\mathrm{w}$ tym punkcie znajdujemy jego piętę achillesową. Życiowe kłamstwo mieszczanina jest tak głęboko zakorzenione w postmodernistycznym obrazie świata, że nie ma on nawet pojęcia, że pod tymi powierzchniowymi pęknięciami leży głęboka sprzeczność. Najlepsza ochrona przed pamięcią polega na produkcji coraz to nowych oszałamiających przeżyć, które za każdym razem tworzą nowy podmiot jako niepowiązaną cząstkę w strumieniu możliwości. Lecz również w tym elastycznym życiu istnieje pewna stała część, która zostaje zachowana: drogocenne Ja, które towarzyszy wszystkim tym doznaniom. To ono jest konsumującym i permanentnie oddającym się innym do konsumpcji ego.

Alienacja pracy i życia stała się do tego stopnia niewidoczna, że każdy moment uległ utowarowieniu. Każdy jest zawsze częścią obiegu gospodarczego jako konsument towarów i uczuć i każdy w każdej chwili musi świadczyć usługi jako producent uczuć i towarów. Poprzez permanentną rewolucję kapitału poczucie wyzysku i alienacji stało się normą. Co prawda jeśli się chce, można tę rewolucję kapitału sobie uzmysłowić, lecz to nic nie przyniesie, ponieważ jest inaczej odczuwane. Emocjonalne spektrum postmodernizmu rozciąga się pomiędzy przeciążeniem, wyobcowaniem i dezorientacją.

Odurzenie i depresja stanowią psychiczne odzwierciedlenie stosunków produkcji w postfordyzmie. Centrum tej gospodarki emocjonalnej pozostaje jednak zawsze odczuwające Ja. Jeśli coś jest dla mnie zbyt silne, oznacza to, że ja jestem zbyt słaby. Dążenie do samookreślenia nie może się uwolnić od oferty rynku, co wskazuje, w jaki sposób powinniśmy się określać; nie można też zdać sobie sprawy z tego, że wolność jest zawsze skrytą zależnością od sił, które uprawiają tę podwójną grę. Podmiot, który czuje się wolny i przeciążony, pozostanie współsprawcą i więźniem kapitalizmu, dopóki nie uświadomi sobie tego, jakie interesy ekonomiczne stoją za wielością ofert życia. Z punktu widzenia kapitału jego rola jest zbieżna $\mathrm{z}$ funkcją pełnioną przez mieszczaństwo jako klasę: realizuje interesy kapitału, sprowadzając ekonomiczne podstawy jego panowania do postaci kwestii czysto technicznych.

Pytanie o winę klasy mieszczańskiej pożegnało się z jej kłamstwem życiowym i stało się pytaniem o ekonomię uczuć. Piętę achillesową postmodernistycznego mieszczaństwa stanowi postać, jaką przyjęła mieszczańska tęsknota za autentycznością - zadowolenie z teraźniejszości oraz duma z pragmatyzmu, który nie pozwala na zadawanie pytań, na które z góry nie ma się odpowiedzi. 


\section{Ekonomia uczuć i poprawność polityczna}

Postmodernistyczna ekonomia uczuć stworzyła broń, za pomocą której ofiary mogą w sposób kompleksowy walczyć z siłami hegemonii. To skomplikowane narzędzie walki powszechnie nazywa się poprawnością polityczną. Pod tą nazwą kryje się pewien po części wewnętrznie sprzeczny zestaw form argumentacji moralnej ${ }^{10}$. Żeby wyrażać się w sposób politycznie poprawny, należy precyzyjnie odróżnić grupę ofiar i grupę sprawców. Pierwszy krok polega na tym, że grupa ofiar rozpoznaje samą siebie i następnie rozpoczyna pracę nad zmianą swojego statusu. W tym celu posługuje się ona klasycznym środkiem oświecenia: jawnością. Publicznie przypisuje sobie status ofiary. Tym samym występuje z prywatnej lub ukrytej niszy i staje się dla siebie oraz dla świata faktem, do którego ten musi się teraz ustosunkować.

Żeby określić swoją pozycję, korzysta się z dwóch powiązanych ze sobą postmodernistycznych praktyk dyskursywnych, których stosowanie prowadzi do wystąpienia typowych dla poprawności politycznej gwałtownych sprzeczności. Z jednej strony pracuje się za pomocą metody dekonstrukcji: rzeczywistość jest ukształtowaną poprzez umowy sumą konwencji. Konwencje są skrystalizowaną władzą, która jest ciągle bezkrytycznie potwierdzana przez codzienność. Mogą one zostać rozpoznane jako dające się zmienić interesy jedynie dzięki ujawnieniu hegemonicznych sił mających moc stanowienia reguł. Druga metoda jest sprzeczna z pierwszą: tutaj wprawdzie własna pozycja zostaje pojęta jako taka, którą ograniczały błędne społeczne reguły, lecz w trakcie swojego tworzenia się zostanie ona uznana za naturalistyczną przyczynę gwałtowności okrzyku protestu. Ofiara rozpoznaje mechanizmy, które stworzyły ją jako ofiarę, i uznaje swoją rolę ofiary za szczególne uzasadnienie swojego oskarżenia, które kategorycznie rozróżnia od uzasadnienia pozycji oskarżonej. Ofiara może atakować, posługując się argumentami, których hegemoniczna władza nie może stosować bez narażenia się na zarzuty.

Sprzeczność polega zatem na jednoczesnym roszczeniu sobie praw do nieesencjalistycznej, kulturowo ukształtowanej tożsamości oraz uznawaniu za niepodważalną prawdę własnej pozycji jako ofiary; prawda ta staje się esencją. Ta mieszanka dekonstrukcji i esencjalizmu odpowiada logice insurekcji, podczas której słabsza strona musi korzystać ze wszystkich środków walki. Będąc kobietą, walczy się o równouprawnienie kobiet i mężczyzn po to, by kiedyś to rozróżnienie nie robiło jakiejkolwiek różnicy. Tym samym zgodnie z zasadami poprawności politycznej ofiara przyjmuje pozycję, która jest uwarunkowana klasowo, jednak bez wykorzystania świadomości klasowej. Zachodzi bowiem istotna różnica pomiędzy stronniczo zaangażowaną świadomością klasową a esencjalistycznym uzasadnieniem roli ofiary w poprawności politycznej.

10 Dla rozeznania nadaje się książka: M. Dusini, T. Edlinger, In aufführungszeichen. Glanz und Elend der Political Correctness, Berlin 2012. 
Dobrą ilustrację tej różnicy i związanych z nią problemów mogą stanowić trudności pojawiające się, kiedy pewnej argumentacji zostaje postawiony zarzut operowania w trybie poprawności politycznej. Jeżeli podczas debaty, która prowadzona jest w ramach struktur poprawności politycznej, argumentacja jednej ze stron zostanie uznana za apologię poprawności politycznej, nierzadko zdarza się, że ta sama opinia zostaje następnie uznana za kolejny dowód na hegemonię drugiej strony. Jednocześnie kiedy roszczenia tego, kto argumentuje w trybie poprawności politycznej, zostają uznane za postawę poprawności politycznej, uznaje on to za kolejną formę represji. Dlaczego tak jest? Kiedy głoszone przez kogoś poglądy socjalistyczne zostają uznane za socjalistyczne, nie odbiera im to prawomocności: jest to co najwyżej nieprzynoszące korzyści żadnej ze stron sporu stwierdzenie oczywistego faktu. Uznanie przeciwnika za socjalistę mogłoby być dyskredytujące jedynie wtedy, jeżeli spór toczy się w społeczeństwie, które wszystko, co socjalistyczne, uznaje za błędne i niebezpieczne. Tak właśnie jest w krajach opanowanych przez neoliberalny fundamentalizm. Dlaczego podobna sytuacja zachodzi w przypadku osób argumentujących w trybie poprawności politycznej? Dzieje się tak po części dlatego, że żyją one w społeczeństwie pełnym przeciwników poprawności politycznej, przede wszystkim jednak dlatego, że odruchowa niechęć do poprawności politycznej jest reakcją na zawartą w niej ukrytą sprzecznośćc ${ }^{11}$.

Różnica pomiędzy stronniczością świadomości klasowej a esencjalistycznym umocowaniem się w roli ofiary polega więc na tym, że stronniczość opiera się na poznaniu, które dostrzega konkretne sprzeczności. Świadomość klasowa nie jest w żadnym razie zdolnością naturalną; nabywa się jej, udzielając odpowiedzi na określone pytania za pomocą dialektycznego myślenia. Jest więc ona dostępna dla wszystkich ludzi, którzy zadają sobie pytanie o sprawiedliwe społeczeństwo. Natomiast poprawność polityczna w swoim aspekcie esencjalistycznym opiera się na niepodlegającej krytyce zasadzie: mężczyzna, który angażuje się w walkę o prawa kobiet, nie może mieć zdania na wiele

11 Zasługuje na uwagę fakt, że najcięższe debaty nad poprawnością polityczną odbywają się na uniwersytetach, w wykształconej klasie średniej, pośród artystów, a zatem w środowiskach, które same sobie stawiają najwyższe wymagania dotyczące równouprawnienia. Nie jest więc ważne, czy społeczeństwo zgadza się lub nie z merytorycznymi roszczeniami równości, ale to, że istnieje niezadowolenie z formy, w jakiej ten pożądany cel ma zostać osiągnięty. Często wrogi komizmowi ton tych debat, w których wręcz czeka się, aż pewna wypowiedź zostanie błędnie zrozumiana, a to zostanie uznane za powód do dalszej eskalacji, przysparza wielu problemów wszystkim stronom pożądających tolerancji. Ta skłonność do zabraniania słów, ponieważ przekazują obraźliwe przesłanie, prowadzi zbyt często na manowce wczesnooświeceniowego moralizmu. Jeśli amerykańscy studenci domagają się, żeby znakować książki, które mają rasistowskie lub seksistowskie treści, demonstrują w ten sposób pewien aspekt poprawności politycznej: podnoszą indywidualne poczucie do rangi reguły powszechnej. Tym samym docieramy do wnętrza pięknej duszy, o której Hegel słusznie powiedział, że jest jedynym absolutnym złem na świecie. Problematyczność tej postawy polega nie na tym, że uświęca ona niewinny indywidualizm, lecz na tym, że dążenie do zmiany świata topi w morzu jałowych kłótni. 
tematów, ponieważ jest mężczyzną. Ze względu na swoją płeć nie mógł zdobyć kobiecego doświadczenia. Biograficzne zakotwiczenie języka w płci, rasie, narodowości i seksualności determinuje stanowisko poprawności politycznej dużo silniej niż analogiczne zakotwiczenie w świadomości, więc stronniczości, socjalistycznej, która może stać się udziałem każdego, kto podejmie się pracy nad zrozumieniem świata. To, że w krajach realnego socjalizmu esencjalizm pochodzenia proletariackiego decydował o karierze życiowej jednostki i jej prawie do „światopoglądu socjalistycznego”, powinno być uznane co najwyżej za przestrogę przed manowcami, na które prowadzi esencjalizm.

Istnieje jeszcze inna strategiczna korzyść płynąca z uzasadniania poglądu za pomocą stanowiska, które nie daje się negocjować. Przyjmowanie konsternacji właściwej dla pozycji ofiary wzmacnia mowę poprawności politycznej wśród opinii publicznej, na którą emocje mają wpływ nieporównywalnie większy niż racjonalne wytłumaczenia. Jeśli przemawia się z pozycji ofiary, każde twierdzenie można uzasadnić niesprawiedliwością i osobistym cierpieniem. Na tym polega kolejna różnica wobec stanowiska klasowego. Argument poprawności politycznej czerpie swoją siłę przekonywania z emocji autentycznie przeżywanych przez ofiarę, a nie z wiedzy na temat świata. Okrzyk dotkniętego wymusza na nas gest zasadniczego oburzenia; przeciwnik jest zasypywany takimi gestami, stara się uzasadnić swoją pozycję, co z kolei daje asumpt do dalszego słusznego oburzenia się. Oburzenie wystrzeliwuje niczym ze zbiornika ciśnieniowego i ze względu na tę niedającą się regulować nadwyżkę zranionych uczuć chce zwrócić uwagę na poprzedzającą historię ucisku. Ostatecznie gest mowy w trybie PC jest dla osoby, która na to długo czekała, możliwością wyrzucenia z siebie swojego bólu i gniewu.

Publiczny dyskurs, który bazując na uczuciu oburzenia, chce krytykować stosunki władzy, może stanowić strategię dla najprzeróżniejszych interesów. W epoce postmodernizmu forma argumentowania oparta na poprawności politycznej tworzy w ten sposób często niezamierzony, ale niezwykle niebezpieczny związek z religijnym fundamentalizmem lub poglądami faszystowskimi. Jeżeli społeczeństwo raz zaakceptuje, że ostatecznym uzasadnieniem dla argumentu nie jest racjonalna podstawa, lecz emocje, nie będzie mogło przeciwstawić się natarciu nowych roszczeń powstałych na podstawie urażonych uczuć. Chociaż z socjalistycznego punktu widzenia chciałoby się, żeby było inaczej, uczucie urażenia nie prowadzi do dobrych decyzji politycznych. W sytuacji, kiedy zniewaga stanowi bezpośrednie źródło zaangażowania politycznego, dominować zaczyna pewna swego mściwość i zawiść. Stąd mowa poprawności politycznej sama równie dobrze może być mową podmiotu postmodernistycznego, jak i fanatyka religijnego. Oboje odmawiają pracy nad polityczną świadomością lub nad racjonalnymi argumentami i na ich miejscu stawiają własne autentyczne uczucie ${ }^{12}$.

12 Resentyment jest siłą napędową światopoglądu fundamentalistycznego: ten, kto czuje się pozbawionym dostępu do przedmiotu pożądania, którym rzekomo „wszyscy inni” dysponują, uważa się za pariasa i dlatego nie musi przestrzegać standardów przestrzeganych w jego otoczeniu. 
Ofiara ma niezbywalne prawo do zostania wysłuchaną i do otrzymania pomocy. Ta moralna prawda cechuje każdą ludzką cywilizację. I w świecie, który jest rozdarty niezliczonymi sprzecznościami, do uzasadnienia własnych czynów często nie pozostaje nic innego jak własne uczucie, które szuka takich partnerów ukształtowanych przez podobne doświadczenia biograficzne. Dlatego też nie dziwi nas, że w centrum dyskursu Cultural Studies znalazły się pojęcia rasy i płci kulturowej, natomiast badania dotyczące kwestii klas stały się niemodne ${ }^{13}$.

W ten sposób każda epoka produkuje własną ekonomię uczuć, której oblicze często jest trudne do rozpoznania dla jej współczesnych. Podczas gdy dla pnącej się w górę klasy mieszczaństwa liczyła się egzystencjalna potrzeba uznania współczucia motorem i gwarantem emancypacji od kłamliwego odgrywania ról szlachectwa, tak już w XIX wieku wszedł ten rozwój w swoją przemysłowo-kulturową fazę. Wzruszenie stało się olejem do smarowania melodramatycznej dramaturgii, która na zmianę z szokującym napięciem do dziś dominuje komercyjny realizm.

Sprowadzaniu współczucia do roli narkotyku dla sentymentalnie nastrojonych mieszczan socjalizm przeciwstawia zimną krew. Tylko chłodne spojrzenie może rozpoznać materialne warunki w taki sposób, że zostaną ujawnione ukryte interesy i sprzeczności. Wszystkie środki obcości [Verfremdung - kategoria u Brechta] mają swoje polityczne pochodzenie w doświadczeniu alienacji. Natomiast wzruszenie wraz z estetycznymi formami odnoszenia się do siebie samego podejrzewane są o upiększanie zwyczajności. Służą bardziej rozkoszowaniu się samym sobą niż czynnemu współczuciu wobec innych.

Zarówno chłód, jak i wzruszenie stanowią w różnych proporcjach uczucia centralne dla różnych postaci postmodernizmu. Utrudniają one jednak wszelkie poznanie poprzez to, że traktowane są na prawach cytatu. Z chłodnego spojrzenia materializmu pozostaje coolness zarozumiałego spojrzenia, które uważa, że wszystko już zobaczyło. Natomiast współczucie duszy mieszczańskiej staje się towarem konsumpcyjnym, który jako codzienna porcja kiczu jest niezbędny dla dobrego samopoczucia niczym kawałek czekolady. I oba uczucia zostają wówczas w swoim ironicznym charakterze podwojone. Cool jest tylko ten, kto wie, że nie spogląda wcale chłodnym okiem. Kiczem może się rozkoszować tylko ten, kto umie kicz przyswoić jako kicz dzięki estetyce campu. Refleksyjne lub paradoksalne uczucia stają się znakiem rozpoznawczym naszej kultury. Jesteśmy zrozpaczeni, ponieważ nie możemy odczuwać nic prawdziwego, śmiejemy się z własnego przerażenia albo obawiamy się popełnienia błędu i jednocześnie reflektujemy, że ten strach już jest fałszywy.

Istnieje niezliczona ilość tych klastrów uczuć, dla których wspólne jest podejmowanie podwójnej oceny. Czucie jest naiwną oceną jakiegoś przeżycia. Lecz już w tym

13 B. Hooks: „Nowadays it is fashionable to talk about race and gender; the uncool subject is class”. Cyt. za: O. Marchart, Cultural Studies, Konstanz 2008, s. 195. 
momencie czucie nie będzie odczuwane, tylko jednocześnie obserwowane, poprzez co czucie i jego obserwacja popadają w stosunek zwrotny, który jest znakiem postmodernistycznych uczuć.

W przeciwieństwie do podwójnie wolnego pracownika u Marksa postmodernistyczny człowiek jest „podwójnie związanym” konsumentem. Musi bez przerwy konsumować nowe uczucia i w tym celu obracać swoimi uczuciami na rynku. Dzisiaj dobrze ukryta sprzeczność mieszczaństwa nie polega już tylko na byciu jednocześnie wyzyskiwaczem i wyzyskiwanym, lecz również na rozczłonkowaniu proletariackiego mieszczanina. Sentymentalna wrażliwość, wyćwiczona we wzruszaniu się i oburzaniu, uchodzi za autentyczny wyraz autentycznych pragnień. I właśnie to prawdziwe Ja powinno być zawsze gotowe do działania - zarówno w życiu społecznym, jak i w stosunkach produkcji. Pozór „autentyczności”, wynaleziony niegdyś w celu ukrycia wewnętrznych sprzeczności klasy mieszczańskiej, jest teraz instrumentalizowany w postaci nowej prawdy. Wszyscy chcą być autentyczni, powinni być autentyczni i mogą być jedynie autentyczni, jeśli chcą przetrwać na rynku dóbr i uczuć.

Wrażliwość sentymentalna idzie w parze z roszczeniem konsumenta, który domaga się, żeby świat oferował odpowiednie środki pozwalające to pragnienie zaspokoić. Dzięki temu wszyscy mogą czuć się jednocześnie ofiarami i wybawicielami. I najbardziej pożądany efekt przyjęcia takiego punktu widzenia polega na tym, że w charakterystycznej dla niego ślepej plamce ginie zupełnie wymiar sprawczości. Dla postmodernistycznego człowieka nie stanowi już problemu to, co dla dawnego mieszczanina stanowiło wstydliwy sekret. Stosunki klasowe tak samo jak wyzysk są bezpiecznie ukryte dzięki wytężonej pracy wkładanej codziennie w utrzymanie równowagi emocjonalnej. Dzisiejszemu mieszczaninowi wydaje się, że może o sobie stwierdzić, że nie należy do żadnej klasy, wpisując się tym samym w starą mieszczańską tradycję.

Ttumaczyt z niemieckiego Maciej Kawecki 
